\title{
Balancing Power and Love Towards Global Stability in the Muslim World
}

\author{
Ahmad Badri Abdullah*
}

The Muslim Ummah is currently suffering from a deteriorating crisis namely the crisis of love and power. This is evident with the recent unfolding events of ruthless actions taken by some extremist groups who have recklessly portrayed Islam as a religion of hatred and violence. The extent of this was unprecedented with other political turmoils in middle-eastern countries which have given rise to calamities and great loss of life among citizens. Moreover, the rise of terrorism in the Muslim world now is the quintessential crime of those who feel powerless and thus seek to undermine the perceived power of a targeted group. These anecdotes exhibit the obsession of power among the Muslims along with the absence of love for fellow humans.

On the other hand, there are other groups in the Ummah overemphasising on the urgency to restore love within the Ummah as if power has no significant role in realising the love. The proponents of this trend believe that issues ranging from cultural or racial conflicts, environmental degradation, and economic inequality can be resolved by the transformation of the heart by enlightening and refining the inner faculty of the human being. The society is perceived as being in dire need of individuals whose actions are the manifestation of their loving and refined hearts.

Love is indeed an impactful impulse in individual and collective societal life. It is a drive to unite the separated which is manifested in a focus on relationships and connection. It is also a predisposition toward helping another person to become complete i.e. to develop their full potential. Paul Tillich, a German philosopher defined love as the other-acknowledging, other-respecting, other-helping drive that reunites the separated. A quantum physicist David Bohm elucidated the pragmatic capacity of love which is "to break the boundaries between peoples, so we can operate as a single intelligence. This is the natural state of the human the world, separation without separateness."

Power could be defined as a generative drive of a living entity to realise itself by increasing its intensity and extensity. It expresses purposefulness, wholeness, and agency. It is also the force that triggers change in the world as well as the means by which new social realities are created. However, the pursuit of one's self-realisation might easily compromise that of others. Nonetheless power is essential in pursuing change and development in individual or collective life, be it in economic, political, social, or educational fields.

Love in Islam is all-encompassing, rather than being restricted to merely a single 
form namely the intimate relation between man and woman. The proclamation of this is indicative in a hadith which was reported by Abu Hurayrah, the Prophet (peace be upon him) said:

By Him in Whose Hand my soul is, you will not enter Paradise unless you believe, and you will not believe unless you love each other. Should I direct you to something that if you constantly do, you would love each other? Spread the greetings of peace among you, (No. 54, The Book of Faith, Sahih Muslim)

It is interesting to note that the Prophet (peace be upon him) associates the salvation of one's soul in paradise to one's social life of loving the other. Ibn al-Qayyim al-Jawziyyah in his book entitled 'The Garden of Lovers' (Rawdhah al-Muhibbin) in which he discusses extensively the subject of love, suggested that the compatibility of the soul is the strongest cause of love since each soul longs for the other soul that possesses similar characteristics. This also shows the capacity of love to unite the separated.

Nonetheless, love without power is sentimental and anemic. In other words, overemphasising love and unity without the space for self-realisation is unconsciously reinforcing the status quo. Love provides potentials whereas power is imperative for such potentials to be brought into reality. Unity or dialogue without power will not be able to create a new reality; in reality, it recreates and reinforces current realities. On the other hand, power without love is indeed reckless, abusive, and likewise prone to maintain or worsen the status $q u o$. Hence, the real challenge is to mediate and search for a balance between the exercise of power and the promotion of love and unity.

The act of walking is an epitome of the feasible measure to mediate between love and power. To walk in a stable way, one need to first move one leg and then the other so as to be always in a dynamic balance. Therefore to reconcile power with love, the time factor is imperative. Despite that, the key to stable walking is that even when one focuses on one leg, he should not forget the other.

This notion of the balance of power and love is prevalent in Islamic juristic and ethical traditions. As an elementary example, in the implementation of Islamic criminal law, which is an exercise of power, there is still a space for love which is manifested in the encouragement for individual reconciliation and forgiveness by the Prophet (peace be upon him) himself, especially on some prescribed punishments ( $h u d u d$ ) offences which infringe both the right of Allah and the right of the individual, such as theft (saraqah), robbery (hirabah), and false accusation of adultery (qazaf). In two hadith the Prophet (peace be upon him) touched on this matter by mentioning: 
Avoid condemning a Muslim to a prescribed punishment whenever you can, and when you can find a way out for a Muslim then release him for it. If the imam errs, it is better that he errs in favour of innocence (pardon) then in favour of guilt (punishment). (No. 1424, Sunan AlTirmizi, No.4384, al-Hakim)

Forgive each other among you for prescribed offences (if committed). When an offence reaches (informed to or tried by) me, it becomes enforceable. (No. 4376, Sunan Abu Daud)

The Islamic ethical guidance in war is another hallmark for the effective management between love and power. It signifies the balance between the two forces according to the time factor. Saidina Abu Bakr, the first Caliph in Islam immediately after the Prophet's death, issued the following instructions to his commander who went on a military campaign to Syria:

Do not kill women, children, or the aged. Do not cut fruitful trees. Do not destroy inhabited places, Do not slay sheep, cow or camel (sic) except for your food. Do not burn bee-hives nor destroy them. Do not steal from the booty and do not be cowardly. (No. 1294, Book of Jihad, Muwattha' Malik)

This injunction clearly elucidates that even in the state of war, which is a battle for power; love for innocent people, children, property, as well as nature should not be absent. Nonetheless, the element of power prevails in such circumstance since the immunity of a civilian will cease if they get involved in the war or threaten Islam. This can be seen when the Prophet (peace be upon him) did not condemn the killing of a woman from Banu Qurayzah who had attacked Khallad ibn Suwayd. These Islamic guidelines on the conduct of war are among others, a clear indication of the approach of searching for the point of balance between love and power.

Maintaining a balancing-loop between power and love is thus imperative in addressing the pressing global issues nowadays. Despite the crises of terrorism and insecurity, there are also other complex and challenging problems faced by our global community. The issues include climate change, food security, water security, economic inequalities, and the spread of diseases. In order to address effectively these issues the two forces of love and power need to be in a state of balance to ensure stability in the global community of our Ummah.

\section{Notes}

* Ahmad Badri bin Abdullah is Research Fellow at IAIS Malaysia (Email: badri@, iais.org.my). 